REVIEW

\title{
Heart and mind: (1) relationship between cardiovascular and psychiatric conditions
}

\author{
S U Shah, A White, S White, W A Littler
}

Postgrad Med J 2004;80:683-689. doi: 10.1136/pgmj.2003.014662

The relationship of our emotions and psyche to heart disease is intriguing. In this article we have reviewed the evidence linking cardiovascular and neuropsychiatric disorders and the possible mechanisms and pathophysiology of this association. This review is derived from Medline searches (1966-2002) using the relevant search terms (psychiatric disease, cardiovascular disease, depression, anxiety, and pathophysiology). Finally, the possible role of using mood enhancing therapies (mainly antidepressants) and their safety in patients with cardiovascular disorders is briefly discussed. In a companion paper, the therapeutic aspects of these two conditions is highlighted.

See end of article for authors' affiliations

Correspondence to: Correspondence to: Department of Cardiology, Ysbyty Gwynedd, Bangor LL57 2PW, UK; saeedshah@miranshah. freeserve.co.uk

Submitted

11 September 2003

Accepted 17 October 2003

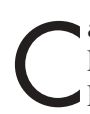
ardiovascular diseases, such as ischaemic heart disease (IHD), hypertension, chronic heart failure, and arrhythmias are highly prevalent conditions contributing 15.3 million deaths in 1996 and accounting for 30\% of the global death toll that year. ${ }^{1-3}$ More specifically, they account for almost half of all deaths in developed countries and $25 \%$ of deaths in developing countries.

Neuropsychiatric illnesses and the use of psychotropic medications are equally prevalent. ${ }^{14}$ The two conditions can merely coexist; however, there are now substantial data supporting a strong relationship between these two prevalent conditions. The interaction of heart and psyche is bidirectional. Emotions and stressful experiences affect the heart directly through the autonomic nervous system and indirectly through neuroendocrine pathways. Conversely, cardiac activity and function can reach conscious awareness and may be experienced as symptoms.

However, psychological aspects of organic illnesses are usually ignored or underdiagnosed. ${ }^{1}$ Physicians often attribute somatic complaints of fatigue, lethargy, insomnia, and loss of appetite to underlying physical condition and medications. There may also be a lack of confidence by physicians in the use of psychotropic drugs in cardiovascular conditions. Although several psychotropic agents have been shown to be cardiotoxic, there are others that have been shown to be safe in cardiac conditions and might actually improve a patient's morbidity. ${ }^{4}$

This article was written in order to review the extent and coexistence of the two groups of diseases and the relationship between cardiovascular diseases and psychiatric conditions.

\section{NEUROPSYCHIATRIC FACTORS AFFECTING PATHOGENESIS AND PROGRESSION OF CARDIOVASCULAR DISEASES (BOX 1) \\ Psychosocial factors}

Psychosocial factors may affect behaviours such as smoking, diet, alcohol, or physical activity that in turn can influence the risk of coronary heart disease. $^{1}$

\section{Personality trait and behavioural pattern} A type A personality (a highly ambitious and aggressive individual) has always been considered a prototype for the development of heart disease. One study conducted on initially healthy individuals showed that those with type A behaviour patterns showed a significant risk of developing IHD compared with type B (calm, laid back, and non-aggressive) individuals. ${ }^{1}$ However, other studies failed to support this association. ${ }^{5}$ These contradictory findings have led to a search for more specific components of type A behaviour that may have a stronger association with IHD. Anger and/or suppressed anger have been suggested to be the pathogenic components of type A personality. Anger, suppressed anger, hostility, antagonistic interactions, cynicism, and mistrust have been associated in long term, prospective studies with an increased incidence of IHD, acute coronary syndromes, and total mortality. ${ }^{6-10}$ An angiographic study by Goodman et al also reported an association between the degree of hostility and prediction of restenosis after percutaneous transluminal coronary angioplasty. ${ }^{11}$

In general, it appears that hostility and anger may predispose more to the initial cardiac event than adversely influence the course of already established coronary artery disease. It is unclear to what degree hostility's effect may be mediated through its influence on other risk factors, such as lack of social supports, smoking, diet, and alcohol use.

\section{Depression}

Major depression is a prevalent and disabling mental illness that is underdiagnosed and undertreated. ${ }^{1}{ }^{4}$ Different degrees of association between depression and IHD have been shown in many epidemiological and observational studies. These studies have shown raised cardiovascular mortality and morbidity rates in patients with diagnosis of depression. ${ }^{12-19}$ The evidence that

Abbreviations: HRV, heart rate variability; $5-\mathrm{HT}$, serotonin; ICD, implantable cardiac defibrillators; IHD, ischaemic heart disease 
Box 1: Psychological and social factors

implicated in the causation of cardiovascular conditions

\section{Psychosocial factors}

- Social class.

- Income.

- Area.

- Type of job.

Type A personality traits

- Anger/suppressed anger.

- Hostility.

- Antagonistic interactions.

- Cynicism.

- Mistrust.

Depression

Anxiety

- Phobic anxiety.

- Acute and chronic mental stress.

depression is a risk factor for the development of IHD is less extensive and somewhat less conclusive. Some prospective studies report a modest association between depression and the incidence of IHD, but others fail to find a correlation. In longitudinal studies of initially healthy, community residents without a history of IHD, depression has been associated with a relative risk between 1.5 and 2.0 for the subsequent development of IHD, myocardial infarction, and cardiac death over moderate to longer periods and is largely independent of traditional risk factors (table 1).

On the other hand, depression and depressive symptoms are found to be common in patients with established IHD. Clinically significant depressive symptoms are found in $40 \%-65 \%$ of patients after a myocardial infarction. ${ }^{20}{ }^{21}$ Although most subjects in these studies have been male, there is evidence that the risk of depression in women with IHD may be twice as high as that of men. ${ }^{13}{ }^{14}$ The prevalence of depression is also increased in patients with stable IHD and in patients who have undergone coronary artery bypass surgery. ${ }^{22}{ }^{23}$ In patients with implantable cardiac defibrillators (ICDs), while most recipients adjust well to living with the implant, a substantial minority suffer anxiety, depression, and anger that appear to be related to the ICD. A large number of studies have reported on the incidence of psychopathology and common psychosocial problems among patients with ICDs. ${ }^{24} 25$

Major depression and subthreshold depressive symptoms, in patients with IHD, have also been shown to confer an increased risk for subsequent cardiac events. ${ }^{26}$ In addition, depression exacerbates, prolongs, and amplifies cardiac symptoms. ${ }^{28}$ Depression also appears to exert a negative prognostic influence on the course and outcome of IHD. In patients with documented IHD, depression predicted cardiac events and was associated with elevated rates of cardiac mortality. ${ }^{28}{ }^{29}$ After myocardial infarction, depression may increase the risk of future coronary events, both over short and longer periods of time. ${ }^{30}$

The relationship between depression and IHD may be mediated through several different behavioural and physiological mechanisms. Depressed individuals may take poorer care of themselves, pay less attention to diet, drink more alcohol, smoke more, have less motivation and energy to exercise regularly, and be less likely to seek medical care. Depression is also associated with poorer adherence to a medical regimen, cardiac risk factor modification, and a rehabilitation and exercise programme. ${ }^{31}$ However, as explained later, depression also has a causal association with the development of IHD explained by various pathophysiological processes.

\section{Anxiety}

Chronic anxiety and anxiety disorders such as panic and phobias appear to exert a negative influence on the heart.

Table 1 Prospective studies of the association between depression and ischaemic heart disease (IHD)

\begin{tabular}{|c|c|c|c|c|c|}
\hline Study & $\begin{array}{l}\text { Total } \\
\text { sample }\end{array}$ & IHD measure & $\begin{array}{l}\text { Follow up } \\
\text { (years) }\end{array}$ & $\begin{array}{l}\text { No of non-fatal and } \\
\text { fatal events }\end{array}$ & Relative risk $(95 \% \mathrm{Cl})$ \\
\hline $\begin{array}{l}\text { Anda et al } \\
(1993)^{12}\end{array}$ & 2832 & $\begin{array}{l}\text { Non-fatal/ } \\
\text { fatal IHD }\end{array}$ & 16 & $\begin{array}{l}205 \text { non-fatal } \\
189 \text { fatal }\end{array}$ & $\begin{array}{l}1.6(1.10 \text { to } 2.40) \\
1.5(1.00 \text { to } 2.30)\end{array}$ \\
\hline $\begin{array}{l}\text { Ariyo et al } \\
(2000)^{119}\end{array}$ & $\begin{array}{l}5888 \\
\text { mortality }\end{array}$ & IHD/all cause & 6 & $\begin{array}{l}606 \text { fatal/non-fatal IHD } \\
270 \text { fatal/non-fatal MI } \\
298 \text { non-fatal angina } \\
614 \text { deaths } \\
122 \text { non-fatal } \\
290 \text { fatal }\end{array}$ & $\begin{array}{l}\text { IHD } 1.11(1.01 \text { to } 1.22) \\
\text { MI } 1.12(0.97 \text { to } 1.29) \\
\text { Angina } 1.13(1.13 \text { to } \\
1.23) \\
\text { Death } 1.13 \text { (1.03 to } \\
1.23 \text { ) }\end{array}$ \\
\hline $\begin{array}{l}\text { Ferketich et al } \\
(2000)^{120}\end{array}$ & 7893 & $\begin{array}{l}\text { Non-fatal/ } \\
\text { fatal IHD }\end{array}$ & 11 & $\begin{array}{l}\text { Men non-fatal } 187 \\
\text { Men fatal } 137 \\
\text { Women non-fatal } 187 \\
\text { Women fatal } 129\end{array}$ & $\begin{array}{l}\text { Men non-fatal } 1.71 \\
\text { (1.14 to } 2.56) \\
\text { Men fatal } 2.34 \text { ( } 1.54 \text { to } \\
3.56) \\
\text { Women non-fatal } 1.73 \\
\text { (1.11 to } 2.68) \\
\text { Women fatal } 0.74(0.40 \\
\text { to } 1.48)\end{array}$ \\
\hline $\begin{array}{l}\text { Ford and Mead } \\
(1998)^{121}\end{array}$ & 1190 & $\mathrm{IHD} / \mathrm{Ml}$ & 40 & 163 non-fatal & IHD 2.1 (1.24 to 2.63 ) \\
\hline $\begin{array}{l}\text { Sesso et al } \\
(1998)^{122}\end{array}$ & 1305 & $\begin{array}{l}\text { Non-fatal/ } \\
\text { fatal }\end{array}$ & 14 & $\begin{array}{l}30 \text { non-fatal } \\
20 \text { fatal }\end{array}$ & IHD 1.5 (0.82 to 2.58$)$ \\
\hline
\end{tabular}

$\mathrm{Cl}$, confidence interval; $\mathrm{Ml}$, myocardial infarction. 
Several studies suggest a relationship between anxiety disorders and increased cardiac outcomes (table 2). High levels of phobic anxiety were associated with an almost fourfold increase in the relative risk for fatal IHD in the Northwick Park study. ${ }^{32}$ In a much larger study, in subjects with no prior history of IHD, a dose-response relationship was found between phobic anxiety and coronary heart disease mortality (relative risk 2.5, 95\% confidence interval 1.00 to 5.96$).{ }^{33}$ Further analysis revealed that this association was caused by an increased risk of sudden death. These findings persisted after adjustment for smoking and other risk factors and in a sample including baseline cases of coronary heart disease. Interestingly, no association was found between phobic anxiety and either non-fatal myocardial infarction or total IHD.

Association between other anxiety disorders and cardiovascular mortality was assessed in another work by Kawachi et al. ${ }^{34}$ Although it showed a significant increase in the relative risk for cardiac mortality, after adjusting for other cardiovascular risk factors, the multivariate odds ratio for fatal coronary heart disease became non-significant. Further analyses of this work also looked at another dimension of anxiety: chronic worrying as a risk factor for coronary heart disease. Overall, worries (particularly about social, financial, and health conditions) were found to be associated with total coronary heart disease including angina and non-fatal and fatal myocardial infarction.

\section{Acute and chronic mental stress}

Acute and long standing stress is shown to increase the risk of IHD. Sudden, acute mental stress has negative cardiovascular consequences. Cardiovascular mortality rises in the month immediately after the death of a loved one. ${ }^{35}$ The incidence of cardiac events also rises immediately after natural disasters and among civilians subjected to military attack. ${ }^{36}$ Such stressors increase heart rate, blood pressure, and myocardial oxygen demands. The effect of acute mental stress on the heart already damaged by pre-existing IHD has been studied extensively. Such stress can precipitate myocardial ischaemia in $30 \%-60 \%$ of IHD patients. ${ }^{37}$ Circumstances and situations leading to intense anger and, to a lesser degree, to anxiety are also potent triggers of myocardial ischaemia. ${ }^{38}{ }^{39}$ Thus, there is a twofold increase in the risk of myocardial infarction in the two hours after an episode of intense anger. ${ }^{40}$

Chronic stresses such as job strain and other forms of work related stress have also been shown to have a very strong association with cardiovascular disease. Job strain has been associated with an increased risk of IHD in previously healthy people. ${ }^{41}{ }^{42}$ Cross sectional and longitudinal studies disclose that both male and female workers in jobs high in strain have a higher prevalence of IHD and a higher incidence of myocardial infarction than those with low job strain. ${ }^{43-45}$

In addition to IHD, acute and chronic stress has also been shown to be associated with lethal arrhythmias and sudden cardiac death. A number of studies report increases in life stress in the months preceding sudden cardiac death. ${ }^{46-53}$ However, many of these studies lack suitable control groups and are subject to systematic reporting bias or employ problematic measures of life stress.

\section{PATHOPHYSIOLOGY}

Psychological stress and conditions such as depression, anxiety, and a specific personality type may cause direct pathophysiological changes (box 2). There is evidence linking neuropsychiatric conditions with hormonal and haematological abnormalities. These include hypothalamic pituitary axis activation, adrenergic hyperactivity, platelet abnormalities leading to increased adhesiveness, raised fibrinogen levels, endothelial dysfunction, raised left ventricular mass, and the progression of carotid atherosclerosis.

\section{Neuroendocrine activation}

A stable endocrine system plays an important part in the overall integrity and normal functioning of the cardiovascular system. ${ }^{54}{ }^{55}$ Potentially, many neuroendocrine pathways exist by which acute or chronic psychiatric conditions may contribute to the development of cardiovascular diseases through metabolic and haemostatic actions. Psychological stress results in hypothalamic-adrenocortical and sympathoadrenal hyperactivity. ${ }^{56-60}$ This can induce raised corticosteroid and catecholamine concentrations leading to multiple metabolic and autonomic effects. Chronic activation of these pathways has been shown to promote atherosclerosis by causing increases in glucose, cholesterol and free fatty acids, and a blunting of the action of insulin, besides a rise in blood pressure. ${ }^{61}$ Sympathoadrenal activation can also contribute to cardiovascular disease through a direct effect of on cardiac function, blood vessels, and platelets. ${ }^{62-65}$

\section{Arrhythmias}

Hyperactivity of the hypothalamic-adrenomedullary axis with a resulting increase in circulating catecholamines can cause increased myocardial irritability and a decreased threshold for induction of ventricular fibrillation. ${ }^{5566}$ Sympathetic stimulation of the heart exerts a proarrhythmic effect. It increases ventricular ectopy and lowers the threshold for inducing ventricular arrhythmias especially in the heart with pre-existing ischaemic damage or electrical instability. ${ }^{67}$ There is an association between increased mortality after myocardial infarction and depression relating to ventricular ectopic activity. Although ectopic activity is not increased in depressed patients, there is evidence that when

\begin{tabular}{|c|c|c|c|c|c|}
\hline Study & $\begin{array}{l}\text { Total } \\
\text { sample }\end{array}$ & IHD measure & $\begin{array}{l}\text { Follow up } \\
\text { (years) }\end{array}$ & $\begin{array}{l}\text { No of non-fatal } \\
\text { and fatal events }\end{array}$ & Relative risk $(95 \% \mathrm{CI})$ \\
\hline $\begin{array}{l}\text { Haines et al } \\
(1998)^{123}\end{array}$ & 3500 & Non-fatal/fatal IHD & 6 & $\begin{array}{l}57 \text { non-fatal } \\
56 \text { fatal }\end{array}$ & $\begin{array}{l}1.26(0.62 \text { to } 2.54) \\
3.77(1.64 \text { to } 8.64)\end{array}$ \\
\hline $\begin{array}{l}\text { Kawachi et al } \\
(1994)^{33}\end{array}$ & 51529 & Non-fatal/fatal IHD & 2 & $\begin{array}{l}128 \text { non-fatal } \\
140 \text { fatal }\end{array}$ & $\begin{array}{l}0.89(0.45 \text { to } 1.79) \\
2.45 \text { (1.00 to } 5.96)\end{array}$ \\
\hline $\begin{array}{l}\text { Kawachi et al } \\
(1994)^{34}\end{array}$ & 2280 & Non-fatal/fatal IHD & 32 & $\begin{array}{l}137 \text { non-fatal } \\
131 \text { fatal }\end{array}$ & $\begin{array}{l}0.71(0.24 \text { to } 2.09) \\
1.94(0.70 \text { to } 5.41)\end{array}$ \\
\hline $\begin{array}{l}\text { Kubzansky et al } \\
(1997)^{124}\end{array}$ & 2280 & Non-fatal/fatal IHD & 20 & $\begin{array}{l}113 \text { non-fatal } \\
86 \text { fatal }\end{array}$ & $\begin{array}{l}2.41(1.40 \text { to } 4.13) \\
0.81(0.45 \text { to } 1.44)\end{array}$ \\
\hline
\end{tabular}


Box 2: Probable pathological processes triggered/induced by psychological factors involved in the aetiology of cardiovascular system abnormalities

Hypothalamic-adrenocortical and sympathoadrenal effects

- $\uparrow$ Cortisol.

- $\uparrow$ Blood glucose.

- $\uparrow$ Cholesterol.

- $\uparrow$ Free fatty acids.

- $\uparrow$ Insulin.

Haematological effects

- $\uparrow$ Plasma fibrinogen.

- $\uparrow$ Platelets aggregation.

- $\uparrow$ Platelet factor 4.

- $\uparrow \beta$-Thromboglobulin.

Cardiac rhythm effects

- Arrhythmias.

- $\downarrow$ Heart rate variability.

Cardiac and vascular effects

- $\uparrow$ Carotid-intima thickness.

- Endothelial dysfunction.

- $\downarrow$ Left ventricular mass.

excessive ectopic activity does occur it has a stronger association with death in patients who are depressed. ${ }^{68}$ Patients who were not depressed experienced little increase in risk associated with ventricular ectopic activity even if they had a low ejection fraction. ${ }^{68}$ This finding fits in well with animal based models pointing to proarrhythmic factors as the link between psychological disorder and sudden cardiac death..$^{5070}$ Experimentally induced psychological stress lowers the ventricular threshold for ventricular fibrillation and increases the frequency of ventricular ectopic beats in animal based models with pre-existing ventricular arrhythmias. $^{70}$

Heart rate variability (HRV) is an important indicator of autonomic nervous system function and stability. ${ }^{54}{ }^{55}$ Blunted or reduced HRV is associated with increased risk of recurrent events in patients with acute coronary syndromes or in survivors of cardiac arrest. ${ }^{71-73}$ In patients with depression there is evidence of a low HRV. ${ }^{74}{ }^{75}$ Patients suffering from depression seem to have higher sympathetic tone and blunted inhibitory reflexes. Interestingly, treatment of these patients with antidepressants has been shown to be associated with increase in HRV and thus a possible improvement in mortality. ${ }^{76} 77$

\section{Effect on fibrinogen}

Fibrinogen is an acute phase reactant protein, raised levels of which are associated with increased risk of cardiovascular disease. ${ }^{78} 79$ Plasma fibrinogen levels have also been found to be associated with several social and psychosocial factors in adulthood, consistent with high rates of IHD in deprived strata of society. ${ }^{80} 81$

\section{Platelet abnormalities}

Platelet dysfunction appears to play a fundamental part in the vulnerability of depressed patients to IHD. ${ }^{82}$ There is evidence of a baseline elevation in platelet reactivity in depressed patients both with and without co-morbid IHD. ${ }^{82-85}$ This heightened activity appears to increase cardiovascular risk and the likelihood of thrombus formation. Increased plasma concentrations of adrenaline and serotonin (5-HT), which have been reported in depressed patients, may contribute to altered platelet function. ${ }^{86}$ In addition, changes in platelet physiological characteristics that adversely affect platelet function, such as increased intraplatelet calcium mobilisation, upregulation of $5-\mathrm{HT}_{2}$ receptors or $\alpha_{2}$-adrenoreceptors, downregulation of 5-HT transporter number, altered second messenger signal transduction, or altered intraplatelet concentrations of monoamines or catecholamines, may also be present in patients with depression and contribute to clotting diathesis. ${ }^{86-91}$

5-HT is a neurotransmitter, and has an integral role in the causation of depression. ${ }^{92}$ Platelets are richly endowed with 5-HT receptors, and platelet aggregation and coronary vasoconstriction in diseased arteries are partly regulated by activation of these receptors. ${ }^{86} 889093$ Platelets from depressed patients have been shown to exhibit increased 5-HT binding density (which normalises on remission of depression) and reduced density of transporter sites ${ }^{88-90}$ Although 5-HT has only a weak thrombogenic effect, it amplifies the response of platelets to other thrombogenic agents. It is therefore possible that 5-HT not only plays a major part in the neurobiology of depression, but probably also influences thrombogenesis. ${ }^{86}$ It has been shown that short term treatment with an antidepressant paroxetine reverses platelet abnormalities in depressed patients without cardiac disease and in depressed patients with coronary artery disease. ${ }^{94}$

Platelet factor 4 and $\beta$-thromboglobulin are proteins, the levels of which are directly proportional to platelet aggregability. Their levels have been found to be raised in patients suffering from major depression and significantly decrease when they are treated with paroxetine. ${ }^{95}$ Increased platelet adhesion has also been shown in circumstances of excessive emotional stress particularly anger and hostility. ${ }^{33-35} 96$

\section{Vascular abnormalities}

Carotid intima-media thickness has been shown to be correlated with coronary heart disease. ${ }^{97} 98$ Several animal and human studies have shown an association between increased intima-media thickness and psychosocial and socioeconomic factors. ${ }^{99-103}$

Endothelial dysfunction is an early manifestation of developing coronary heart disease. Endothelium plays an important part in determining the vasomotor tone and prothrombotic/antithrombotic and inflammatory processes. Impairment of endothelial function has been shown to be associated with sympathetic over activity and its manifestations in various animal and human studies. ${ }^{104-105}$

\section{Increased left ventricular mass}

Left ventricular hypertrophy on electrocardiography has been shown to be strongly associated with clinical cardiovascular end points. ${ }^{106}{ }^{107}$ There are at least two major studies showing the association of psychosocial conditions and left ventricular hypertrophy on electrocardiography. ${ }^{108-110}$ However, in another study psychosocial variable or stressors were not found to be significantly associated with increased left ventricular mass on echocardiography. ${ }^{11}$

\section{CONCLUSION}

In conclusion, there is quite convincing evidence regarding relationship between diseases of the psyche and conditions affecting the cardiovascular system. This association is particularly strong in patients with depression and phobic anxiety. Depressive symptoms as well as depressive caseness seem to be influential in predicting IHD. It is, however, unclear what the effect of duration of depression is on risk. In case of phobic anxiety, there is a clear association with increased risk of sudden cardiac death. It is probably related 
to increased susceptibility to arrhythmias. Like depression, this association with increased myocardial mortality has clinical therapeutic implications. The question whether treating patients with these psychiatric conditions may influence their cardiovascular risk profile needs further exploration and research. Active management of these patients with psychiatric illnesses can potentially reduce the morbidity and mortality associated with coronary heart disease. ${ }^{112-116}$ Progress will depend on a greater understanding of the pathophysiological and biochemical links between depression and coronary heart disease and more precise identification of the aspects of depression that confer risk and of the population groups most at risk. The safety of antidepressants is also a factor that should be considered before prescribing these medications in vulnerable patients (unstable symptoms or patients with recent myocardial infarction). More recent work regarding the newer antidepressants in the SADHAT ${ }^{117}$ and SADHART ${ }^{118}$ trials has shown the safety of at least one selective 5-HT reuptake inhibitor. Hence, in patients with significant depressive symptoms and even recently unstable IHD, this class of medications can be used with greater confidence and safety.

\section{Authors' affiliations}

S U Shah, University Hospital Birmingham and University of Birmingham, Birmingham, UK

A White, S White, W A Littler, University Hospital Birmingham, Birmingham, UK

\section{REFERENCES}

1 Rosenman RH, Brand RJ, Jenkins CD, et al. Coronary heart disease in the Western Collaborative Group Study: final follow-up experience of 81/2 years. JAMA 1975;233:872-7.

2 Murray CJL, Lopez AD. The global burden of disease. Cambridge, MA: Harvard School of Public Health, 1996.

3 Howson CP, Reddy SK, Ryan TJ, et al. Control of cardiovascular diseases in developing countries. Washington, DC: National Academy Press, 1998.

4 American Psychiatric Association. Diagnostic and statistical manual of mental disorders. 4th Ed. Washington, DC: American Psychiatric Press, 1994.

5 Matthews KA, Gump BB. Chronic work stress and marital dissolution increase risk of post trial mortality in men from the Multiple Risk Factor Intervention Trial (MRFIT). Arch Intern Med 2002; 162:309-15.

6 Miller TQ, Smith TW, Turner CW, et al. A meta-analytic review of research on hostility and physical health. Psychol Bull 1996;119:322-48.

7 Barefoot JC, Larsen L, von der Leith L, et al. Hostility, incidence of acute myocardial infarction and mortality in a sample of older Danish men and women. Am J Epidemiol 1995; 142:477-84.

8 Kawachi I, Sparrow D, Spiro A, et al. A prospective study of anger and coronary heart disease: the Normative Aging Study. Circulation 1996;94:2090-5.

9 Shekelle RB, Gale M, Ostfield A, et al. Hostility, risk of coronary heart disease, and mortality. Psychosom Med 1983;45:109-14.

10 Gallacher JE, Yarnell JW, Sweetnam PM, et al. Anger and incident of heart disease in the Caerphilly study. Psychosom Med 1999;61:446-54.

11 Goodman M, Quigley J, Moran G, et al. Hostility predicts restenosis after percutaneous transluminal coronary angioplasty. Mayo Clin Proc 1996;71:729-34.

12 Anda R, Williamson D, Jones D, et al. Depressed affect, hopelessness, and the risk of ischemic heart disease in a cohort of US adults. Epidemiology 1993;4:285-94.

13 Barefoot JC, Schroll M. Symptoms of depression, acute myocardial infarction, and total mortality in a community sample. Circulation 1996;93:1976-80.

14 Scheier MF, Matthews KA, Owens JF, et al. Optimism and rehospitalization after coronary artery bypass surgery. Arch Intern Med 1999;159:829-35.

15 Aromaa A, Raitasalo R, Reunanen A, et al. Depression and cardiovascular diseases. Acta Psychiatr Scand 1994;377(suppl):77-82

16 Ford DE, Mead LA, Chang PP, et al. Depression is a risk factor for coronary artery disease in men. Arch Intern Med 1996;158:1422-6.

17 Hippisley-Cox J, Fielding K, Pringle M. Depression as a risk factor for ischemic heart disease in men: population based case-control study. BMJ 1998:316:1714-19.

18 Vogt T, Pope C, Mullooly J, et al. Mental health status as a predictor of morbidity and mortality. Am J Public Health 1994;84:227-31.

19 Wassertheil-Smoller S, Applegate WB, Berge K, et al. Change in depression as a precursor of cardiovascular events. SHEP Cooperative Research Group (Systolic Hypertension in the Elderly). Arch Intern Med 1996;56:553-61.

20 Frasure-Smith N, Lespérance F, Talajic M. Depression following myocardial infarction: Impact on 6-month survival. JAMA 1993;270:1819-25.
21 Lespérance F, Frasure-Smith N, Talajic M. Major depression before and after myocardial infarction: its nature and consequences. Psychosom Med 1996;58:99-110.

22 Carney RM, Rich MW, Tevelde A, et al. Major depressive disorder in coronary artery disease. Am J Cardiol 1987:60:1273-5.

23 McKhann GM, Borowicz LM, Goldsborough MA, et al. Depression and cognitive decline following coronary artery bypass grafting. Lancet 1996;349:1282-4

24 Dunbar SB, Kimble LP, Jenkins LS, et al. Association of mood disturbance and arrhythmia events in patients after cardioverter defibrillator implantation. Depress Anxiety 1999;9:163-8.

25 Duru F, Buchi S, Klaghofer R. How different from pacemaker patients are recipients of implantable cardioverter-defibrillators with respect to psychosocial adaptation, affective disorders, and quality of life? Heart $2001 ; 85: 375-9$.

26 Sullivan MD, LaCroix AZ, Baum C, et al. Functional status in coronary artery disease: a one-year prospective study of the role of anxiety and depression. Am J Med 1997; 103:348-56.

27 Carney RM, Rich MW, Freedland KE, et al. Major depressive disorder predicts cardiac events in patients with coronary artery disease. Psychosom Med 1988;50:627-33.

28 Frasure-Smith N, Lespérance F, Talajic M. Depression and 18-month prognosis after myocardial infarction. Circulation 1995;91:999-1005.

29 Frasure-Smith N. In-hospital symptoms of psychological stress as predictors of long-term outcome after acute myocardial infarction in men. Am J Cardiol 1991:67:121-7.

30 Musselman DL, Evans DL, Wemeroff CB. The relationship of depression to cardiovascular disease: epidemiology, biology, and treatment. Arch Gen Psychiatry 1998;55:580-92.

31 Carney RM, Freedland KE, Eisen S, et al. Major depression and medication adherence in elderly patients with coronary artery disease. Health Psychol 1995; 14:88-90.

32 Haines AP, Imeson JD, Meade TW. Phobic anxiety and ischaemic heart disease. BMJ 1987;295:297-9.

33 Kawachi I, Colditz GA, Ascherio A, et al. Prospective study of phobic anxiety and risk of coronary heart disease in men. Circulation 1994;89:1992-7.

34 Kawachi I, Sparrow D, Vokonas PS, et al. Symptoms of anxiety and risk of coronary heart disease: the Normative Aging Study. Circulation 1994:90:2225-9.

35 Kaprio J, Koskenvuo M, Rita H. Mortality after bereavement: a prospective study of 95,647 persons. Am J Public Health 1987;77:283-7.

36 Jiang W, Babyak M, Krantz DS, et al. Mental stress-induced myocardial ischemia and cardiac events. JAMA 1996;21:1651-6.

37 Rozanski A, Bairey CN, Krantz DS. Mental stress and the induction of silent myocardial ischemia in patients with coronary artery disease. N Engl J Med 1988;318:1005-12.

38 Krantz DS, Kop WJ, Santiago HT, et al. Mental stress as a trigger of myocardial ischemia and infarction. Cardiol Clin 1996;14:271-87.

39 Campbell S, Barry J, Rebecca GS, et al. Active transient myocardial ischemia during daily life in asymptomatic patients with positive exercise tests and coronary artery disease. Am J Cardiol 1986;57:1010-16.

40 Jiang W, Babyak M, Krantz DS, et al. Mental stress-induced myocardial ischemia and cardiac events. JAMA 1996;21:1651-6.

41 Bosma H, Peter R, Siegrist J, et al. Two alternative job stress models and the risk of coronary heart disease. Am J Public Health 1998;88:68-74.

42 Karasek RA, Theorell TG, Schwartz J, et al. Job, psychological factors, and coronary heart disease: Swedish prospective findings and US prevalence findings using a new occupational inference method. Adv Cardiol 1982;29:62-87

43 Alfredsson L, Spetz CL, Theorell T. Type of occupation and near-future hospitalization for myocardial infarction and some other diagnoses. Int J Epidemiol 1985;14:378-88.

44 Williams RB, Barefoot JC, Califf RM, et al. Prognostic importance of social and economic resources among medically treated patients with angiographically documented coronary artery disease. JAMA 1992;267:520-4

45 Johnson JV, Stewart W, Hall EM, et al. Long-term psychosocial work environment and cardiovascular mortality among Swedish males. Am J Public Health 1996;86:324-31

46 Engel GL. Sudden and rapid death during psychological stress: folklore or folk wisdom? Ann Intern Med 1971;74:771-82.

47 Reich P, DeSilva RA, Lown B, et al. Acute psychological disturbance preceding life-threatening ventricular arrhythmias. JAMA 1981;246:233-5.

48 Myers A, Dewan HA. Circumstances attending 100 sudden deaths from coronary artery disease with coroner's necropsies. $\mathrm{Br}$ Heart J 1975;7:1133-43.

49 Rissanen V, Romo M, Siltanen P. Premonitory symptoms and stress factors preceding sudden death from ischemic heart disease. Acta Med Scand 1978;204:389-96

50 Lown B, DeSilva RA. Roles of psychological stress and autonomic nervous system changes in provocation of ventricular premature complexes. Am J Cardiol 1978:41:979-85.

51 Follick MJ, Gorkin L, Capone RJ, et al. Psychological stress as a predictor of ventricular arrhythmias in a post-myocardial infarction population. Am Heart J 1988; 116:32-6.

52 Kamarck T, Jennings JR. Biobehavioral factors in sudden cardiac death. Psychol Bull 1991;109:42-75.

53 Carney RM, Saunders RD, Freedland KE, et al. Association of depression with reduced heart rate variability in coronary artery disease. Am J Cardiol 1995;76:562-4 
54 Spyer KM. Central nervous system control of the cardiovascular system. In Bannister R, ed. Autonomic failure: a textbook of clinical disorders of the autonomic nervous system. Oxford, UK: Oxford University Press, 1988:56-79.

55 Sheilds RW. Functional anatomy of the autonomic nervous system. J Clin Neurophysiol 1993;10:2-13.

56 Suarez EC, Kuhn CM, Schanberg SM, et al. Neuroendocrine, cardiovascular, and emotional responses of hostile men: the role of interpersonal challenge. Psychosom Med 1998;60:78-88.

57 Wyatt RJ, Portnoy B, Kupfer DJ, et al. Resting plasma catecholamine concentrations in patients with depression and anxiety. Arch Gen Psychiatry 1971;24:65-70.

58 Roy A, Pickar D, DeJong J, et al. Norepinephrine and its metabolites in cerebrospinal fluid, plasma, and urine: relationship to hypothalamicpituitary-adrenal axis function in depression. Arch Gen Psychiatry 1988;45:849-57.

59 Smagin GN, Heinrichs SC, Dunn AJ. The role of CRH in behavioral responses to stress. Peptides 2001;22:713-24.

60 Troxler RG, Sprague EA, Albanese RA, et al. The association of elevated plasma cortisol and early atherosclerosis as demonstrated by coronary angiography. Atherosclerosis 1977;26:151-62.

61 Ross R, Harker L. Hyperlipidaemia and athero-sclerosis. Science 1976;193:1094-100.

62 Lovis WJ, Doyle AE, Anavekar SN. Plasma nor-adrenaline concentration and blood pressure in essential hypertension, phaeochromocytoma and depression. Clin Soc 1975:48:239S-42.

63 Goldstein DS. Plasma catecholamines and essential hypertension: an analytical review. Hypertension 1983;5:86-99.

64 Anfossi G, Trovati M. Role of catecholamines in platelet function: pathophysical and clinical significance. Eur J Clin Invest 1996;26:353-70.

65 Kahn JP, Perumal AS, Gully RJ, et al. Correlation of type A behaviour with adrenergic receptor density: implications for coronary artery disease pathogenesis. Lancet 1987;ii:937-9.

66 Follick MJ, Ahern DK, Gorkin L, et al. Relation of psychosocial and stress reactivity variables to ventricular arrhythmias in the Cardiac Arrhythmia Pilot Study (CAPS). Am J Cardiol 1990;66:63-7

67 Lown B, DeSilva RA. Roles of psychological stress and autonomic nervous system changes in provocation of ventricular premature complexes. Am J Cardiol 1978:41:979-85.

68 Frasure-Smith N, Lesperance F, Talajic M. Depression and 18 month prognosis after myocardial infarction. Circulation 1995;91:999-1005.

69 Corbalan R, Verrier R, Lown B. Psychological stress and ventricular arrhythmias during myocardial infarction in the conscious dog. Am J Cardiol 1974;34:692-6.

70 Skinner JE, Lie JT, Entman ML. Modification of ventricular fibrillation latency following coronary artery occlusion in the conscious pig. Circulation 1975;51:656-66.

71 Kleiger RE, Miller PJ, Bigger TJ, et al. Decreased heart rate variability and its association with increased mortality after acute myocardial infarction. Am J Cardiol 1987;59:256-62.

72 LaRovere MT, Specchia G, Mortana A, et al. Baroreflex sensitivity, clinical correlates, and cardiovascular mortality among patients with a first myocardial infarction: a prospective study. Circulation 1988;78:816-24

73 Billman GE, Schwartz PJ, Stone HL. Baroreceptor reflex control of heart rate: a predictor of sudden cardiac death. Circulation 1982;66:874-80.

74 Miyawaki E, Salzman C. Autonomic nervous system tests in psychiatry: implications and potential uses of heart rate variability. Integrated Psychiatry $1991 ; 7: 21-8$

75 Carney RM, Saunders RD, Freeland KE, et al. Association of depression with reduced heart rate variability in coronary artery disease. Am J Cardiol 1995;76:562-4

76 Rechlin T, Weis M, Claus D. Heart rate variability in depressed patients and differential effects of paroxetine and amitriptyline on cardiovascular autonomic functions. Pharmacopsychiatry 1994;27:124-8.

77 Balogh S, Fitzpatrick DF, Hendricks SE, et al. Increases in heart rate variability with successful treatment in patients with major depressive disorder. Psychoparmacol Bull 1993;29:201-6.

78 Meade TW, Ruddock V, Stirling Y, et al. Fibrinolytic activity, clotting factors, and long term incidence of ischaemic heart disease in the Northwick Park Heart Study. Lancet 1993;342:1076-9.

79 Wilhelsmen L, Svardsudd K, Korsan-Bengesten K, et al. Fibrinogen as a risk factor for stroke and myocardial infarction. N Engl J Med 1984;311:501-5.

80 Brunner EJ, Davey Smith G, Marmot MG, et al. Childhood social circumstances and psychosocial and behavioural factors as determinants of plasma fibrinogen. Lancet 1996;347:1008-13.

81 Brunner EJ, Davey Smith G, Marmot MG, et al. When does cardiovascular risk start? Past and present socioeconomic circumstances and risk factors in adulthood. J Epidemiol Community Health 1999:53:757-64.

82 Musselman DL, Tomer A, Manatunga AK, et al. Exaggerated platelet reactivity in major depression. Am J Psychiatry 1996;153:1313-7.

83 Markowitz JH, Mathews KA. Platelets and coronary heart disease:potential psychophysiologic mechanisms. Psychosom Med 1991;53:643-68.

84 Markowitz JH. Hostility is associated with increased platelet activity in coronary heart disease. Psychosom Med 1998;60:586-91.

85 Larrson PT, Hjemdahl P, Olsson G, et al. Altered platelet function during mental stress and adrenaline infusion in humans: evidence for an increased aggregability in vivo as measured by filtragometry. Clin Sci 1989;76:369-76.

86 DeClerck F. Effects of serotonin on platelets and blood vessels. J Cardiovasc Pharmacol 1991;17(suppl 5):S1-S5
87 Ashton JH, Ogletree ML, Michel IM, et al. Cooperative mediation by serotonin S2 and thromboxane A2/prostaglandin $\mathrm{H} 2$ receptor activation of cyclic flow variation in dogs with severe coronary artery stenosis. Circulation 1987:76:952-9

88 Biegon A, Weizman A, Karp L, et al. Serotonin 5-HT2 receptor binding on blood platelets: a peripheral marker for depression? Life Sci 1987;41:2485-92.

89 Biegon A, Grinspoon A, Blumenelt B, et al. Increased serotonin 5-HT2 receptor binding on blood platelets in suicidal men. Psychopharmacology 1990;100:165-7.

90 Pandy GN, Pandey PG, Janicak PG. Platelet serotonin-2 binding sites in depression and suicide. Biol Psychiatry 1990;28:215-22.

91 Osim EE, Wyllie JH. Evidence for loss of 5-hydroxytryptamine from circulating platelets. J Physiol (Lond) 1982;326:25P-6.

92 Owens MJ, Nemoerof CB. Role of serotonin in the pathophysiology of depression: focus on the serotonin transporter. Clin Chem 1994;40:288-95.

93 Ashton JH, Benedict CR, Fitzgerald C, et al. Serotonin as mediator of cyclic flow variations in stenosed canine coronary arteries. Circulation 1986;73:572-8

94 Musselman DL, Knight BT, Baron A, et al. Effects of paroxetine treatment on platelet reactivity in patients with major depression (abstract 86 ). Presented at the 37th annual meeting of the American College of Neuropsychopharmacology, Puerto Rico, December 1998.

95 Laghirissi-Thode F, Wagner WR, Pollock BG, et al. Elevated platelet factor 4 and beta-thromboglobulin plasma levels in depressed patients with ischaemic heart disease. Biol Psychiatry 1997;42:290-5.

96 Markowitz JH. Hostility is associated with increased platelet activity in coronary heart disease. Psychosom Med 1998;60:586-91.

97 Mathur KS, Kashyap SK, Kumar V. Correlation of the extent and severity of atherosclerosis in the coronary and cerebral arteries. Circulation 1963;27:929-34.

98 Young W, Gofman JW, Tandy R, et al. The quantitation of atherosclerosis. III. The extent of correlation of the degrees of atherosclerosis within and between the coronary and cerebral vascular beds. Am J Cardiol 1969;6:300-8.

99 Manuck SB, Kaplan JR, Adams MR, et al. Effects of stress and the sympathetic nervous system on coronary artery atherosclerosis in the cynomolgus macaque. Am Heart J 1988;116(1 pt 2):328-33.

100 Williams JK, Vita JA, Manuck SB, et al. Psychosocial factors impair vascular responses of coronary arteries. Circulation 1991;84:2146-53.

101 Kaplan JR, Manuck SB, Clarkson TB, et al. Social stress and atherosclerosis in normocholesterolemic monkeys. Science 1983;220:733-5.

102 Kaplan JR, Clarkson TB, Manuck SB. Pathogenesis of carotid bifurcation atherosclerosis in cynomolgus monkeys. Stroke 1984;15:994-1000.

103 Kaplan JR, Pettersson K, Manuck SB, et al. Role of sympathoadrenal medullary activation in the initiation and progression of atherosclerosis. Circulation 1991;84(6 suppl):VI23-32.

104 Strawn WB, Bondjers G, Kaplan JR, et al. Endothelial dysfunction in response to psychosocial stress in monkeys. Circ Res 1991;68:1270-9.

105 Yeung AC, Vekshtein NI, Krantz DS, et al. The effect of atherosclerosis on the vasomotor response of coronary arteries to mental stress. N Engl J Med 1991;325:1551-6.

106 Kannel WB, Cobbs J. Left ventricular hypertrophy and mortality-results from the Framingham study. Cardiology 1992;81:291-8.

107 Mandawat MK, Wallbridge DR, Pringle SD, et al. Heart rate variability in left ventricular hypertrophy. Br Heart J 1995;73:139-44.

108 Kohara K, Hara N, Hiwada K. Left ventricular mass index negatively correlates with heart rate variability in essential hypertension. Am J Hypertens 1995; 8: 183-8.

109 Schnall PL, Pieper C, Schwartz JE, et al. The relationship between "job strain", workplace diastolic blood pressure and left ventricular mass index. Results of a case control study (published erratum appears in JAMA 1992;267:1209). JAMA 1990;263:1929-35.

110 Siegrist J, Peter R, Motz W, et al. the role of hypertension, left ventricular hypertrophy and psychosocial risks in cardiovascular disease; prospective evidence from blue collar men. Eur Heart J 1992;13(suppl D):89-95.

111 Markowitz JH, Raczynski JM, Lewis CE, et al. Lack of independent relationship between left ventricular mass and cardiovascular reactivity to physical and psychological stress in the Coronary Artery Risk Development in Young Adults ( CARDIA) Study (see comments). Am J Hypertens 1996:9:915-23.

112 Friedman M, Thoresen CE, Gill JJ, et al. Alteration of type A behaviour and its effect on cardiac recurrences in post myocardial infarction patients: summary results of the Recurrent Coronary Prevention Project. Am Heart J $1986 ; 112: 653-65$.

113 Frasure-Smith N, Prince R. The ischaemic heart disease life stress monitoring program: impact on mortality. Psychosom Med 1985;47:431-45

114 Jones DA, West RR. Psychological rehabilitation after myocardial infarction: multicentre randomised controlled trial. BMJ 1996;313:1517-21.

115 Taylor CB, Miller NH, Smith PM, et al. The effect of a home-based, casemanaged, multi-factorial risk-reduction program on reducing psychological distress in patients with cardiovascular disease. Journal of Cardiopulmonary Rehabilitation 1997; 17:157-62.

116 Frasure-Smith N, Lespeance F, Prince RH, et al. Randomised trial of homebased psychosocial nursing intervention for patients recovering from myocardial infarction. Lancet 1997;350:473-9.

117 Shapiro PA, Lesperance F, Frasure-Smith N, et al. An open label preliminary trial of sertraline for treatment of major depression after acute myocardial infarction (the SADHAT trial). Am Heart J 1999;137:1100-6.

118 Glassman AH, O'Conner CM, Califf RM, et al. Sertalaine treatment of major depression in patients with acute $\mathrm{MI}$ or unstable angina (SADHART trial). JAMA 2002;288:701-14. 
119 Ariyo AA, Haan M, Tangen CM, et al. Depressive symptoms and risks of coronary heart disease and mortality in elderly Americans. Circulation 2000;102: 1773-9.

120 Ferketich AK, Schwartzbaum JA, Frid DJ, et al. Depression as an antecedent to heart disease among women and men in the NHANES I study. Arch Intern Med 2000;160:1261-8.

121 Ford DE, Mead LA. Depression is a risk factor for coronary artery disease in men: the precursors study. Arch Intern Med 1998;158:1422-6.
122 Sesso HD, Kawachi I, Vokonas PS. Depression and the risk of coronary heart disease in the Normative Aging Study. Am J Cardiol 1998;82:851-6.

123 Haines AAP, Imeson JD, Meade TW. Phobic anxiety and ischaemic heart disease. BMJ 1987;295:297-9.

124 Kubzansky LD, Kawachi I, Spiro A, et al. Is worrying bad for your heart? A prospective study of worry and coronary heart disease in the normative aging study. Circulation 1997;95:818-24.

FILLER

doi: 10.1136/pgmi.2004.021501

\section{The rise of troponin}

$\mathrm{n}$ recent years the use of troponin testing to monitor myocardial damage has become more pervasive and prominent, replacing the old style CK-MB measurement. Troponin elevation is a marker of cardiac injury and high risk, it is also raised in a minority of acute coronary syndrome patients. However, it is important for clinicians to realise that a single rise in troponin levels is of indeterminable significance. An appropriate series of tests over time, fitting in with the right clinical picture, is of most value.

The troponin complex in striated muscle fibres has three distinct subtypes and c-troponinI is believed to be the one present only in cardiac muscle. Consequently, c-troponin-I is released when there is an assault to the myocardium and this is what laboratory testing picks up (some laboratories may measure the troponin-T subunit; this, however, has been found to be less specific and less sensitive). Interpretation of results can be confusing and there are several caveats to be aware of. A positive c-troponin-I level means that cardiac muscle contents have leaked out of cells. The primary reason why this occurs is in response to injury. There are multiple causes of cardiac muscle injury that includes acute coronary events, but there is also a whole spectrum of disorders that can cause a rise in troponin. The largest study of this subject ${ }^{1}$ showed that all of the following were associated with raised ctroponin-I levels. Pulmonary embolism, ${ }^{2}$ congestive cardiac failure, cardiomyopathy, myocarditis, rhabdomyolosis, chest contusions, sepsis, mural thrombi, prosthetic heart valves, neoplasms, radiation induced coronary stenosis, homocystinuria, systemic lupus erythematosus, and rheumatoid arthritis. Surprisingly, high troponin levels have also been found in cocaine abusers and marathon runners.

Some of these are obviously significant while others merely represent a normal response to a physiological event; c-troponin-I can therefore be distinctly raised in many "noncardiac" disorders. The rise is evidence of cardiac damage per se and the relative importance of this should be determined by the state of the patient.

The troponin test is a valuable and sensitive one but always needs to be assessed in the cold light of the clinical scenario as its specificity to acute coronary syndromes can be questionable, especially on a one-off basis. ${ }^{3}$ Perhaps the advancement of this ultimate biochemical test leads us round in full circle when we attempt to clarify its rise. That is, to a thorough clinical history taking.

P Grant

Timaru Hospital, Timaru, South Canterbury, New Zealand; drpaul.grant@orange.net

\section{REFERENCES}

1 Khan IA, Tun A, Wattanasauwan N, et al. Elevation of serum cardiac troponin I in non-cardiac and cardiac diseases other than acute coronary syndromes. Am J Emerg Med 1999;17:225-9.

2 Mehta NJ, Jani K, Khan IA. Clinical usefulness and prognostic value of elevated cardiac troponin I levels in acute pulmonary embolism. Am Heart J 2003;145:821.

3 Klein Gunnewiek JM, Van De Leur JJ. Elevated troponin T concentrations in critically ill patients. Intensive Care Med 2003;29:2317-22. 